Pediat. Res. 3: 525-531 (1969)

Enzyme activity

glycogen glycogen synthetase phosphorylase

rhesus muscle

\title{
Glycogen Synthetase, Phosphorylase, and Glycogen Content of Developing Rhesus Muscle
}

\author{
R. M. BoceK ${ }^{[28]}$, G. M. BAsinger, and C.H.BeATtY \\ Departments of Biochemistry, Oregon Regional Primate Research Center, Beaverton, Oregon \\ and The University of Oregon Medical School, Portland, Oregon, USA
}

\section{Extract}

Total glycogen synthetase and synthetase I (glucose 6- $\mathrm{PO}_{4}$ independent) and total phosphorylase and phosphorylase $a$ activities were determined in muscle from fetal, neonatal, infant, and adult rhesus monkeys (Macaca mulatta) and correlated with glycogen concentrations. On the basis of nitrogen content, glycogen levels in fetuses in the 55- to 65-day series were higher than those in fetuses in the 100-day series, but similar to those in the fetuses near term (table I). Both glycogen synthetase and phosphorylase activities were demonstrated histochemically in the immature muscle fibers from fetuses at 55,62 , and 65 days of gestation. Total synthetase activity (assayed with $10 \mathrm{mM}$ glucose $6-\mathrm{PO}_{4}$ ) was demonstrated quantitatively at 78 days of gestation; this activity was highest at term (table II). No synthetase I activity could be found in the 78- and 90-day series (table II); hence, it is suggested that in fetal muscle, synthetase $\mathrm{D}$ is responsible for the high levels of glycogen present early in gestation. No correlation between the glycogen content and the percentage of synthetase I present could be found in fetal muscle (fig. 1). Total phosphorylase, lowest at 78 days of gestation, increased almost 10 -fold by term (table II). No significant phosphorylase $a$ activity could be demonstrated at 78 days; however, by 90-100 days, phosphorylase $a$ activity was present and remained at about the same level $(2-7 \%)$ thereafter.

It is concluded that the enzymes for glycogen formation and degradation are present in the immature muscle fibers of the rhesus fetus as early as the first third of gestation ( 55 days). The ratio of total synthetase to phosphorylase activities favors glycogen deposition in the younger fetus (78-125 days) and glycogen breakdown in the fetus at term.

\section{Speculation}

In adult animals, control of muscle glycogen metabolism depends greatly on hormonal activity; insulin promotes glycogen formation by increasing synthetase D to I conversion, and epinephrine causes glycogenolysis by promoting phosphorylase $a$ formation while depressing synthetase activity. The role of hormonal control of glycogen metabolism may be less critical in fetal muscle than it is in adult muscle. If synthetase $\mathrm{D}$ is the active form of the enzyme in glycogen formation in fetal muscle, it would appear that at the cellular level, insulin is a less important regulator of glycogen synthesis than a metabolite control. 


\section{Introduction}

On the basis of wet weight of muscle, glycogen stores in fetal liver and muscle of a number of mammalian species, including man, increase during the latter portion of gestation to levels three to four times higher than those of the adult and then are rapidly depleted at birth [4, 11]. We have demonstrated in vitro that glycogen turnover occurs in muscle from rhesus monkey fetuses (Macaca mulatta) as early as 90 days gestational age (54\% of term) and that the potential for glycogenolysis is greater in the more mature fetal muscle (90-95\% of term) than in the younger fetal or adult muscle [4].

Glycogen turnover is regulated mainly by reciprocal changes in the activities of two key enzymes, glycogen synthetase or UDP glucose: glycogen $\alpha-4$ glucosyl transferase (EG. 2.4.1.11) and phosphorylase or $\alpha$-1,4-glucan: orthophosphate transferase (EC. 2.4. 1.1) [18]. These two enzymes appear to exist in two forms, glycogen synthetase I (independent) and D (dependent) and phosphorylase $a$ and $b$. Synthetase D and phosphorylase $b$ require the activators glucose 6-phosphate (Glc-6-P) and adenosine-5-monophosphate (5'-AMP), respectively. Because of the differences in glycogen content and the in vitro metabolism of glycogen in fetal muscle at various gestational ages, we investigated the activities of these enzymes in developing rhesus muscle.

The ontogeny of total glycogen synthetase (determined with added Glc-6-P) has been studied in developing chick embryo muscle [13]. Total phosphorylase activity (plus 5'-AMP) and phosphorylase $a$ (minus $5^{\prime}$-AMP) have also been demonstrated in chick embryo muscle $[8,21]$. Studies of glycogen and associated enzymes in liver of fetal and neonatal guinea-pigs [16] and in fetal rat [15] have been reported; however, the relations between glycogen content and the total and active forms of the enzymes of glycogen synthesis and degradation have not been investigated either in fetal liver or in fetal muscle of any species. Therefore, in order to correlate muscle glycogen with pertinent enzymic activities during developmental stages of the monkey, muscle from fetuses at various gestational ages and from neonatal, infant, and adult rhesus monkeys was analyzed for glycogen content and for glycogen synthetase and phosphorylase activities. Glycogen synthetase was assayed with (total activity) and without (I form) added Glc-6-P and phosphorylase with (total activity) and without (phosphorylase $a$ ) added $5^{\prime}$-AMP. Because it is difficult to obtain sufficient tissue for quantitative analysis of enzyme activities in fetuses less than 78 days of age, histochemical techniques were used to demonstrate total synthetase and phosphorylase activities in the fetal muscle fibers.
Studies of problems associated with the development of the human fetus are severely restricted by the lack of sufficient tissue and the limited possibilities for adequately controlled experimental conditions. Therefore, we chose the rhesus fetus as our experimental model because subhuman primates are biologically more similar to humans than are the lower animals. VAN Wagenen and Catchrole [25] have investigated the physical growth of the rhesus monkey and concluded that the pattern of growth parallels in a foreshortened, but remarkably similar form, that of man. The differentiation of muscle fibers for the rhesus and man has been shown histochemically to be similar $[1,12]$.

\section{Methods}

Muscle samples from male and female fetal (50-160 days gestational age), neonatal (1-4 days of age), infant (2-6 weeks of age), and adult rhesus monkeys (Macaca mulatta) were obtained [4]. Both arm and leg muscles from the younger fetuses were pooled for an individual sample. Biceps-triceps muscle was taken from the older fetuses and infants and either biceps-triceps or sartorius muscle was taken from the adult. Samples were trimmed free of observable fat, frozen immediately, and stored in liquid nitrogen.

Samples for glycogen determination were weighed while frozen and immediately digested in $30 \% \mathrm{KOH}$. The alkali digests of adult muscle were extracted with diethyl ether to remove lipid. Glycogen was precipitated with ethyl alcohol and washed by resuspending in alcohol, and concentration was determined by the anthrone method [3]. Samples for glycogen fractions were homogenized in 10\% trichloroacetic acid (TCA); the glycogen was isolated from the supernatant (TCAsoluble) and from the $\mathrm{KOH}$ digestate of the tissue (residual glycogen) [3].

Samples for enzyme assay were pulverized in a mortar and pestle and cooled to liquid nitrogen temperature. Aliquots of the powdered tissue (200-300 $\mathrm{mg}$ ) were transferred to previously weighed glass conical homogenizing tubes containing $1 \mathrm{ml}$ of the appropriate medium chilled to dry ice temperature and quickly weighed without thawing. During homogenization $(1 \mathrm{~min}$ ), the tubes were held in $70 \%$ glycerol maintained at -18 to $-20^{\circ}$ for phosphorylase and -8 to $-10^{\circ}$ for synthetase assay. Muscle for synthetase assay was homogenized in $1.5 \mathrm{ml} 0.25 \mathrm{M}$ sucrose$0.001 \mathrm{M}$ EDTA, pH 8.5. Samples for phosphorylase activity were homogenized in $1 \mathrm{ml}$ of $60 \%$ glycerol containing $0.03 \mathrm{M} \mathrm{NaF}$ and $0.001 \mathrm{M}$ EDTA [10] plus $1 \mathrm{ml}$ of $0.15 \mathrm{M}$ citrate buffer, $\mathrm{pH} 6.0$, containing 0.03 M NaF, 0.001 M EDTA and $0.025 \mathrm{M}$ freshly prepared cysteine, and diluted further with an additional $3 \mathrm{ml}$ 
of the citrate buffer-cysteine reagent. The homogenized tissues were extracted at $4^{\circ}$ for $15 \mathrm{~min}$ with frequent shaking and centrifuged $\left(600 \times g, 15 \mathrm{~min}, 0-2^{\circ}\right)$. Aliquots of the supernatant were used for enzyme assay and nitrogen determination.

Total glycogen synthetase (plus $10 \mathrm{mM}$ Glc-6-P) and synthetase I (minus Glc-6-P) were determined as previously described [5]. Synthetase D activity was calculated from the difference between the activities of total synthetase and synthetase I. Activities are expressed as $\mu$ moles UDP formed $/ \mathrm{min} / 100 \mathrm{mg} \mathrm{N}$.

Total phosphorylase (plus 5'-AMP) and phosphorylase $a$ (minus $5^{\prime}$-AMP) were determined as previously described [5] except that the incubation mixture consisted of $0.5 \mathrm{ml}$ of citrate buffer-cysteine reagent, 0.25 $\mathrm{ml}$ of $4 \%$ glycogen in $0.04 \mathrm{M} \mathrm{NaF}, 0.05 \mathrm{ml}$ of the supernatant, and $0.2 \mathrm{ml}$ of $80 \mathrm{mM}$ glucose $1-\mathrm{PO}_{4}$, with or without $5 \mathrm{mM}$ AMP. Results are expressed as $\mu$ moles $\mathrm{P}$ produced $/ \mathrm{min} / 100 \mathrm{mg} \mathrm{N}$. Nitrogen content of the supernatant was determined as previously described [5].

Glycogen synthetase and phosphorylase were demonstrated histochemically on frozen sections of fetal muscle [5]. Glycogen was demonstrated histologically with the periodic acid-Schiff's reaction and confirmed by digestion of the PAS-positive material with malt diastase [19]. In most instances, duplicate assays were made on each homogenized sample. Duplicate muscle samples were usually obtained from each animal.

\section{Results and Discussion}

On the basis of wet weight, the glycogen content of muscle from 50- to 100-day-old fetuses was similar to that of the adult (table I). Glycogen concentration, however, increased about twofold by 120 days and was highest at 160 days ( $97 \%$ of term). Within $24 \mathrm{~h}$ after birth, muscle carbohydrate reserves were depleted to varying degrees. In four 1-day-old animals the glycogen contents were $3.4,5.0,13.2$, and 18.4 $\mathrm{mg} / \mathrm{g}$ wet weight (duplicate muscle samples). This variation probably reflected differences in the stress of birth and conditions immediately after birth, including activity of the newborn. The nutritional state of the neonates was considered satisfactory. The newborns, separated from their mothers as soon as possible, were kept in incubators and usually accepted bottle feedings within a few hours after birth. Values obtained for glycogen content of fetal muscle (wet weight) at various gestational ages and of neonatal muscle agreed with

Table I. Nitrogen and glycogen content and percentage residual glycogen in fetal, neonatal, and adult skeletal muscle of the rhesus monkey ${ }^{1}$

\begin{tabular}{|c|c|c|c|c|c|}
\hline $\begin{array}{l}\text { Series age, } \\
\text { days }\end{array}$ & $\mathrm{No}^{2}$ & $\begin{array}{c}\text { Nitrogen, } \\
\mathrm{mg} / 100 \mathrm{mg} \text { tissue } \\
\text { wet wt }\end{array}$ & $\begin{array}{l}\text { Glycogen, } \\
\text { mg/g tissue } \\
\text { wet wt }\end{array}$ & $\begin{array}{l}\text { Glycogen, } \\
\mathrm{mg} / 100 \mathrm{mg} \\
\mathrm{N}\end{array}$ & $\begin{array}{c}\text { Residual glycogen, } \\
\%^{3}\end{array}$ \\
\hline \multicolumn{6}{|l|}{ Fetus } \\
\hline $50-65$ & 5 & $0.70 \pm 0.02$ & $7.94 \pm 0.5(8)$ & $113 \pm 8.6$ & $8.6 \pm 9.2(4)$ \\
\hline 78 & 5 & $1.19 \pm 0.02(4)$ & $9.3 \pm 0.4(11)$ & $78 \pm 3.3$ & $9.3 \pm 0.5$ \\
\hline 90 & 5 & $1.26 \pm 0.06(6)$ & $9.8 \pm 0.5(15)$ & $78 \pm 3.8$ & $10.1 \pm 0.5(9)$ \\
\hline 100 & 3 & $1.56,1.56$ & $10.0 \pm 0.5(12)$ & $64 \pm 3.3$ & $15.1 \pm 1.9(5)$ \\
\hline 120 & 6 & $2.22 \pm 0.05(8)$ & $22.0 \pm 0.5(19)$ & $99 \pm 2.2$ & $11.3 \pm 0.6(13)$ \\
\hline 150 & 4 & $2.49 \pm 0.08(5)$ & $23.6 \pm 1.4(18)$ & $95 \pm 5.6$ & $16.0 \pm 1.8(11)$ \\
\hline 160 & 6 & $2.72,2.67$ & $27.6 \pm 1.2(17)$ & $102 \pm 4.3$ & $12.8 \pm 0.9(9)$ \\
\hline \multicolumn{6}{|l|}{ Neonate } \\
\hline 4 & 2 & $2.88 \pm 0.06(3)$ & $3.4 \pm 0.4(14)$ & $12 \pm 1.4$ & $52.0 \pm 2.6$ \\
\hline Adult & 14 & $3.18 \pm 0.06$ & $8.1 \pm 0.6$ & $25 \pm 1.9$ & $36.6 \pm 1.0$ \\
\hline
\end{tabular}

1 Values are means \pm SE. Numbers in parentheses are the number of muscle samples in each series if they differ from the number of animals. Muscle samples were obtained from the gastrocnemius and soleus in 50- to 100-day fetal series, from the gastrocnemius in the older fetal and neonatal series, and from the sartorius and biceps in the adult.

${ }^{2}$ Number of animals in each series.

${ }^{3}$ Percentage of total glycogen remaining after extraction of muscle with $10 \%$ trichloroacetic acid. 
values obtained in vitro from muscles of rhesus fetuses and neonates [4].

Although these variations in glycogen content during fetal life are striking, they do not accurately reflect metabolic activity, since a threefold increase in dry weight of muscle occurs from $32 \%$ of term to $2-6$ weeks after birth. The percentage dry weight for fetal muscle, for example, was $7.4 \pm 1.1 \% \mathrm{SE}, \mathrm{n}=3$, at $50-55$ days; $9.1 \pm 0.2 \%, \mathrm{n}=3$, at $62-65$ days; and $10.6 \pm 0.2$, $\mathrm{n}=5$, at $75-78$ days.

Previously we found that in fetal muscle, dry weight increased from $12 \%$ at 90 days to about $20 \%$ at term and to $22 \%$ at $2-6$ weeks after birth [1]; however, biochemical data more commonly are expressed in terms of nitrogen content, since metabolic activity is associated more directly with the protein content of a given tissue than with wet or dry weight values [24]. When calculated on the basis of nitrogen content of muscle, glycogen levels of fetuses in the 50- to 65-day series were significantly higher than those of fetuses in the 78-day series ( $p<0.005)$, and about fourfold higher than those of the adult. The lowest levels in fetal muscle were found at 100 days. By 120 days, however, the glycogen concentrations increased and were similar to values at 50-65 days. No further changes in glycogen levels occurred until term. Concentrations at 4 days after birth were one-half those of adult values.

The percentage of total glycogen represented by the residual or the TCA-insoluble fraction varied from about 9 to $16 \%$ during gestation; however, no consistent change with development was seen even though glycogen content (on the basis of either wet weight or nitrogen) varied in the different fetal series. After birth, the percent residual fraction increased to about $52 \%$ of the total glycogen. The precipitous fall in glycogen stores accompanying birth, therefore, depleted the TCA-soluble form to a greater extent than it did the residual. In the newborn, TGA-soluble glycogen, in addition to being the larger store, also appears to be a more readily available source of energy than is residual glycogen. Although the physiological significance of the TCA-soluble and residual glycogen fractions has been questioned, we have demonstrated that the ${ }^{14} \mathrm{C}$ from glucose- $U-{ }^{14} \mathrm{C}$ is incorporated at different rates into the two fractions in red and white muscle of the rat in vivo and in vitro [6], and others have shown that the TCA-soluble fraction is more sensitive to nutritional states and hormonal effects than is the residual glycogen fraction [23].

Little is known about the size distribution of glycogen macromolecules in developing fetal muscle. The small variation found in the percent residual fraction throughout the period of gestation in relation to the change at birth indicates that the glycogen formed may be quantitatively uniform. Glycogen content in liver of humans from fetal age 13.5 to 26 weeks was structurally similar to that of children 6 weeks- 11 years of age, measured by average length of the glucosyl chains and by the absorption of the glycogen-iodine complex [7]. It can be assumed, therefore, that the glycogen in the developing fetal muscle does not differ qualitatively from that in mature muscle. The morphology of the glycogen particles from embryonic muscle appears to be intermediate between the $\beta$-particles of adult muscle and the $\alpha$-particles typical of liver [14]; however, the subunits of glycogen particles found in embryonic muscle resemble those in adult muscle.

Comparison of synthetase and phosphorylase activities in fetal, neonatal, and adult muscle is shown in table II. Total glycogen synthetase activity increased with the development of the fetus and reached adult levels by 155 days. Although substantial total glycogen synthetase activity was present in fetal muscle at 78 and 90 days, this activity was the Glc-6-P dependent or D-form of the enzyme, since synthetase I activity did not differ significantly from zero; the range for the mean $\pm 2 \mathrm{SE}$ was 2.9 to -1.1 for the 78-day period and 3.1 to -0.5 for the 90 -day series. By 100 days, however, synthetase I represented $14 \%$ of the total activity. This activity increased to $22 \%$ by 125 days and remained at this level through birth. No data were available from the 2 - to 6 -week-old infant scries. Low activity of the glycogen synthetase phosphatase enzyme, which converts the $\mathrm{D}$ to the I form, may account for the low percentage of synthetase $I$ in the earlier fetal series. Continuous utilization of ATP appears necessary to maintain the enzyme in the phosphorylated $\mathrm{D}$ form in heart and diaphragm muscle [22]. Since no synthetase I could be demonstrated in the 78- and 90-day-old fetus, it must be assumed that adequate supplies of ATP were available above that required for synthetic processes in the muscle cell. We have shown in rhesus fetuses, on the basis of nitrogen and noncollagenous protein nitrogen content, that glucose utilization and lactate production, oxygen consumption and $\mathrm{CO}_{2}$ production [2] and succinic dehydrogenase activity [1] are as great in 90-day fetal muscle as in infant muscle. Therefore, mechanisms for ATP generation from both aerobic glycolysis and the citric acid cycle are available to the cell. PrRas et al. [20] found that both $\mathrm{D}$ and $\mathrm{I}$ forms of rat muscle glycogen synthetase are inhibited by ATP, ADP, and $\mathrm{P}_{\mathrm{i}}$. Within physiological concentrations of glucose $6-\mathrm{PO}_{4}$, the $\mathrm{D}$ form is more strongly inhibited by ATP than is the I form. They concluded that, under most conditions, probably only the latter is significantly active. Enzymatic activity depends, therefore, not only on the level of activators but on the relative concentration of inhibitors. It is difficult to estimate the internal environ- 
ment of the fetal muscle cell, but if the relative activities of these two enzymes in vitro are consistent with those in vivo, it appears that the conversion to the I form is absent or minimal in the young rhesus fetus and that the $\mathrm{D}$ form of the enzyme is active in synthesizing glycogen.

Total phosphorylase activity was lowest in the younger fetal series and highest near term (table II). Adult values for total phosphorylase were about twice those of the immediate prenatal and postnatal series. The phosphorylase $a$ activity present at 78 days of gestation did not differ significantly from zero; however, phosphorylase $a$ activity was similar in all series from 90 days on, including the adult. The percentage of phosphorylase in the active or $a$ form was higher in the 90and 100-day series. By 125 days, the percentage of $a$ form decreased to one-third or less of the previous values and remained at this level in the older fetal, neonatal, and infant series. In adult muscle, phosphorylase $a$ was about $2 \%$ of the total activity. This is several times lower than the percentage of phosphorylase $a$ previously reported for adult rhesus sartorius [5]. The difference is probably due to improved analytical techniques.

The high total phosphorylase activity in the 155-day series is consistent with previous in vitro data, which showed that the magnitude of glycogenolysis was greater in rhesus muscle near term than in younger fetal or infant muscle [4]. The substantial phosphorylase and synthetase activities present at 90 days fetal age indicate that glycogen stores in the rhesus fetus as early as $50 \%$ of term are available as an energy source. This observation also concurs with our previous results [4], which indicated that glycogen turnover could be demonstrated under aerobic and anaerobic conditions as early as 90 days fetal age. There is no

Table II. Glycogen synthetase and phosphorylase activities in muscle from fetal, neonatal, and infant rhesus monkeys $^{x}$

\begin{tabular}{|c|c|c|c|c|c|c|c|c|}
\hline \multirow[t]{2}{*}{ Series } & \multirow[b]{2}{*}{ No. ${ }^{2}$} & \multicolumn{3}{|c|}{$\begin{array}{c}\text { Glycogen synthetase, } \\
\mu \text { moles UDP } / \mathrm{min} / 100 \mathrm{mg} \mathrm{N}\end{array}$} & \multirow[b]{2}{*}{ No. ${ }^{2}$} & \multicolumn{2}{|c|}{$\begin{array}{c}\text { Phosphorylase, } \\
\mu \text { moles } \mathrm{P} / \mathrm{min} / 100 \mathrm{mg} \mathrm{N}\end{array}$} & \multirow[b]{2}{*}{$\% a^{8}$} \\
\hline & & $\begin{array}{r}\text { 1. Total } \\
\text { activity }^{3}\end{array}$ & $\begin{array}{l}\text { 2. Synthetase } \\
I^{4}\end{array}$ & $\% I^{5}$ & & $\begin{array}{l}\text { 3. Total } \\
\text { activity }^{6}\end{array}$ & $\begin{array}{l}\text { 4. Phosphor- } \\
\text { ylase } a^{7}\end{array}$ & \\
\hline \multicolumn{9}{|l|}{ Fetal } \\
\hline 78 days & 5 & $17.2 \pm 1.4^{9}$ & $0.9 \pm 1.0^{10}$ & - & 4 & $9.1 \pm 1.2^{9}$ & $2.3 \pm 1.2^{10}$ & - \\
\hline 90 days & 5 & $16.8 \pm 1.0^{9}$ & $1.3 \pm 0.9^{10}$ & - & 2 & $\begin{array}{c}14.1,12.3 \\
(2)\end{array}$ & $\begin{array}{c}4.3,3.1 \\
(2)\end{array}$ & 30 \\
\hline 100 days & 6 & $20.6 \pm 1.2^{9}$ & $2.8 \pm 0.4^{11}$ & 14 & 8 & $18.3 \pm 0.7^{9}$ & $4.7 \pm 0.6$ & 25 \\
\hline 125 days & 10 & $27.0 \pm 1.2^{11}$ & $6.2 \pm 1.2$ & 22 & 11 & $40.3 \pm 2.4^{9}$ & $2.6 \pm 0.4$ & 7 \\
\hline $\begin{array}{l}155 \text { days } \\
\text { Neonatal }\end{array}$ & 10 & $33.2 \pm 1.3$ & $8.0 \pm 1.4^{11}$ & 25 & 8 & $80.0 \pm 2.2^{9}$ & $3.1 \pm 0.8$ & 5 \\
\hline $\begin{array}{l}1 \text { day } \\
\text { Infant }\end{array}$ & 10 & $27.0 \pm 1.3^{11}$ & $6.1 \pm 1.0^{12}$ & 22 & 10 & $71.0 \pm 11^{9}$ & $4.4 \pm 0.7$ & 6 \\
\hline $2-6$ weeks & 10 & $27.0 \pm 2.0^{11}$ & - & 一 & 9 & $\begin{array}{c}71.6 \pm 11^{9} \\
(3)\end{array}$ & $3.8 \pm 0.7$ & 6 \\
\hline Adult & 18 & $33.8 \pm 1.9$ & $4.9_{ \pm 0.5}$ & 14 & 18 & $\frac{160 \pm 17}{(7)}$ & $\begin{array}{c}3.8 \pm 0.4 \\
(7)\end{array}$ & 2 \\
\hline \multicolumn{4}{|c|}{$\begin{array}{l}{ }^{1} \text { Values are means } \pm \mathrm{SE} \text {; three fetuses each in the } \\
78-, 90-, 100 \text {-day fetal and neonatal series; six fe- } \\
\text { tuses at } 125 \text { days and five at } 155 \text { days; four infant } \\
\text { and nine adult animals. Numbers in parentheses } \\
\text { are the number of animals in a series if it differs } \\
\text { from that given. } \\
{ }^{2} \text { Number of muscle samples assayed. } \\
{ }^{3} \text { With } 10 \text { mM Glc-6-PO } \\
{ }^{4} \text { Without additional Glc-6-PO } \text { PO }_{4} \text {. }\end{array}$} & \multicolumn{5}{|c|}{$\begin{array}{l}{ }^{5} \text { Ratio of column } 2 \text { over column } 1: \frac{-\mathrm{Glc}-6-\mathrm{PO}_{4}}{+\mathrm{Glc}-6-\mathrm{PO}_{4}} \times 100 . \\
{ }^{6} \text { With }+5 \mathrm{mM} \text { AMP. } \\
{ }^{7} \text { Without additional AMP. } \\
{ }^{8} \text { Ratio of column } 4 \text { over column } 3: \frac{-\mathrm{AMP}}{+\mathrm{AMP}} \times 100 \text {. } \\
{ }^{9} \mathrm{p} \text { value for comparison with adult series }<0.001 \text {. } \\
{ }^{10} \text { Values not significantly different from zero. } \\
{ }^{11} \mathrm{p} \text { value for comparison with adult series }<0.05 \text {. } \\
{ }^{12} \text { Six samples, three animals. }\end{array}$} \\
\hline
\end{tabular}


apparent reason why total synthetase activity reaches adult levels by 155 days fetal age whereas total phosphorylase activity is less than one-half of the adult value $2-6$ weeks after birth. Maximal phosphorylase activity was attained in avian muscle 6-8 weeks ex ovo [8]. If the activities of the enzymes assayed in fetal muscle can be correlated with activities in vivo, the ratio of the activities of total synthetase to total phosphorylase could be indicative of the balance between the potential for glycogen synthesis and breakdown. Thus, the ratio of total synthetase to total phosphorylase would favor glycogen deposition at 78 days fetal age $(16.1: 8.3)$ and glycogenolysis at 155 days (33.5:80.7).

The relation between glycogen content, expressed as $\mathrm{mg} / 100 \mathrm{mg} \mathrm{N}$, and the activities of the glycogen synthetic and degradative enzymes is shown in figure 1. Difficulty in obtaining sufficient tissue prevented quantitative enzyme analysis of muscle from animals less than 75 days fetal age. Total glycogen synthetase and phosphorylase activities, however, were demonstrated histochemically in the immature fibers from fetuses at 55, 62, and 65 days of gestation. These fibers also showed an intensive PAS reaction for glycogen. In these sections, muscle fibers accounted for an estimated $25-33 \%$ of the total cross-sectional area; the rest of the tissue was occupied by a diffuse, watery matrix. The histochemical data, showing a high concentration of glycogen in the muscle cells of the younger fetus, agreed with the chemical data for glycogen levels corrected for nitrogen content rather than with the low glycogen levels reported in terms of wet weight.

In adult mouse muscle, Danforth [9] found an inverse correlation between the percentage of synthetase in the I form and the glycogen concentration; that is, synthetase I activity increases only when glycogen stores are almost completely exhausted. In the present study, no such relation was found in the rhesus fetal muscle, since both glycogen levels and synthetase I activity rose with gestational age (fig. 1). Glycogen has been shown to inhibit synthetase phosphatase, the enzyme that dephosphorylates synthetase $\mathrm{D}$ to form synthetase I [17]. If this phosphatase is lacking or inactive in fetal muscle, then glycogen would be ineffective in the postulated product inhibition control mechanism for glycogen synthesis normally present in adult muscle [9]. The noncorrelation between the glycogen content and the activities of the enzymes studied is further emphasized in the 1-day neonatal muscle. Although glycogen concentration $(\mathrm{mg} / 100 \mathrm{mg}$ $\mathrm{N}$ ) varied almost fivefold within $24 \mathrm{~h}$ after birth (fig. 1), no significant change in activities could be found in the total or the active forms of synthetase or phosphorylase enzymes.

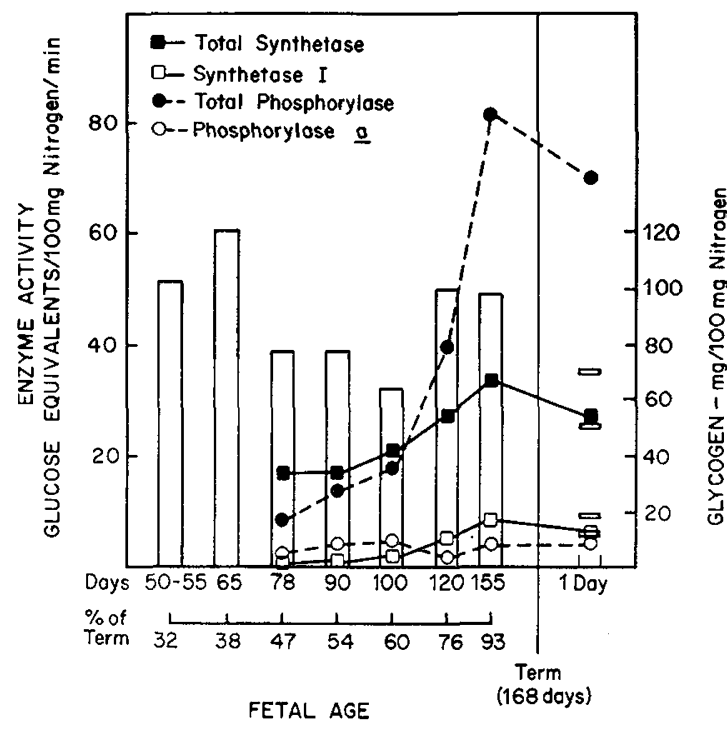

Fig. 1. Correlation between glycogen content in $\mathrm{mg} /$ $100 \mathrm{mg}$ nitrogen (indicated by the bars) and glycogen synthetase and phosphorylase activities in fetal and neonatal muscle. Values for enzyme activities are given in terms of glucose equivalents/min/200 mg nitrogen added or removed from glycogen. Glycogen concentrations in 1-day neonates are indicated by the segmented horizontal bars.

In the liver of fetal guinea-pig, substantial glycogen synthetase activity was present before glycogen accumulated [16]; however, both glycogen and synthetase activity increased concomitantly at about $85 \%$ of term. Phosphorylase activity, also present at an early stage of gestation in the guinea-pig, rose sharply at about $92 \%$ of term and reached a maximum after birth. Although our data follow a completely different pattern from those of KORNFELD and BROwN [16] for rat liver, the same conclusions can be drawn. Both sets of data suggest that glycogen accumulation in fetal tissues (liver and muscle) cannot be attributed solely to changes in activity of the enzymes measured.

\section{Summary}

The glycogen content and activities of the enzymes associated with glycogen synthesis and degradation, the total and active forms of glycogen synthetase and phosphorylase, were determined in skeletal muscle from fetal rhesus monkeys at various gestational ages and compared with those in neonatal and adult muscle. No consistent correlation could be found between the glycogen content (in terms of nitrogen content) and enzyme activities. On the basis of total enzyme activi- 
ties, the balance between synthetic and breakdown processes would seem to favor glycogen deposition by almost 2:1 at 78 days fetal age and glycogenolysis by a similar factor near term.

\section{References and Notes}

1. Beatty, G.H.; Basinger, G. M. and Bocek, R. M.: Differentiation of red and white fibers in muscle from fetal, neonatal and infant rhesus monkeys. J.Histochem. Cytochem. 15: 93-103 (1967).

2. Beatty, G. H.; Basinger, G. M. and Bocek, R. M. : Oxygen consumption and glycolysis in fetal, neonatal, and infant muscle of the rhesus monkey. Pediatrics 42: 5-16 (1968).

3. Beatty, G.H.; Peterson, R. D.; Bocek, R. M. and West, E.S.: Comparison in control and severely diabetic, alloxanized rats of phosphate fractions, glycogen and fat. Amer. J. Physiol. 196: 1246-1249 (1959).

4. BoceK, R. M. and BeArty, C. H.: Glycogen metabolism in fetal, neonatal, and infant muscle of the rhesus monkey. Pediatrics 40: 412-420 (1967).

5. Bocer, R.M. and Bearty, C.H.: Glycogen synthetase and phosphorylase in red and white muscle of the rat and rhesus monkey. J. Histochem. Cytochem. 14: 549-559 (1966).

6. Bocek, R. M.; Peterson, R. D. and Beatty, C.H. Glycogen metabolism in red and white muscle. Amer. J. Physiol. 210: 1101-1107 (1966).

7. Bourne, E.J.; MaLean, A. and Pridham, J.B.: The structure and deposition of human-liver glycogens. Biochem.J. 98: 678-681 (1966).

8. Cosmos, E.: Enzymatic activity of differentiating muscle fibers. 1. Development of phosphorylase in muscles of the domestic fowl. Develop. Biol. 13: 163-181 (1966).

9. DANFORTH, W.H.: Glycogen synthetase activity in skeletal muscle. Interconversion of two forms and control of glycogen synthesis. J.biol. Chem. 240: 588-593 (1965).

10. Danforth, W.H.; Helmreich, E. and Cori, C.F.: The effect of contraction and of epinephrine on the phosphorylase activity of frog sartorius muscle. Proc.nat. Acad. Sci., Wash. 48: 1191-1199 (1962).

11. Dawes, G.S.: Foetal and neonatal physiology; p. 215 (Year Book Medical Publishers, Chicago 1968).

12. Duвowitz, V.: Enzyme histochemistry of skeletal muscle. II. Developing human muscle. J. Neurol. Neurosurg. Psychiat. 28: 519-524 (1965).

13. Grillo, T.A.I. and Ozone, K.: Uridine-diphosphate glucose-glycogen synthetase activity in the chick embryo. Nature, Lond. 195: 902-903 (1962).
14. Heuson-Stiennon, J.-A. and Drochmann, P.: Localization and structure of glycogen morphogenesis of striated muscle. J. Micr. 6: 639-656 (1967).

15. JACQuot, R. and Kretchmer, N.: Effect of fetal decapitation on enzymes of glycogen metabolism. J.biol. Chem. 239: 1301-1304 (1964).

16. Kornfeld, R. and BRown, D.H.: The activity of some enzymes of glycogen metabolism in fetal and neonatal guinea pig liver. J. biol. Chem. 238: 1604 1607 (1963).

17. Larner, J.; Villar-Palasi, C.; Goldberg, N. D. ; Bishop, J.S.; Hurjung, F.; Wenger, J.I.; SAsko, H. and BRown, N. B. : Hormonal and nonhormonal control of glycogen synthesis-control of transferase phosphatase and transferase I kinase; W.J.WHELAN, Control of glycogen metabolism. Fed. Europ. Biochem. Soc.Symp., pp.1-18 (Academic Press, New York, N.Y. 1968).

18. LELOIR, L.F.: Regulation of glycogen metabolism. Int.Symp. Enzymatic Aspects Metabolic Regulation. Nat. Cancer Inst. Monogr. 27, pp.3-18 (1967).

19. McManus, J.F.A. and Mowry, R.W.: Staining methods histologic and histochemical, pp. 126, 145 (Hoeber, New York 1960).

20. Piras, R.; Rothman, L.B. and Gabib, E.: Regulation of muscle glycogen synthetase by metabolites. Differential effects on the I and D forms. Biochemistry 7: 56-66 (1968).

21. Rinaudo, M.T. and BRuno, R.: $\alpha$-Glucan-phosphorylase in the striated muscle of the developing embryo of Gallus domesticus. Enzymologia 34: 45-50 (1968).

22. Søvik, O.; Øye, I. and Rosell-Perez, M.: The effect of anoxia, 2,4-dinitrophenol and 2-deoxyglucose on muscle glycogen synthetase. Biochim. biophys. Acta 124: 26-33 (1966).

23. Stetten, D., Jr. and Stetten, M.R.: Glycogen metabolism. Physiol. Rev. 40: 505-532 (1960).

24. Umbreir, W.W.; Burris, R.H. and Stauffer, J.F.: Manometric techniques; 3rd ed., p.138 (Burgess, Minneapolis 1957).

25. Van Wagenen, G. and Catchpole, H. R. : Physical growth of the rhesus monkey (Macaca mulatta). Amer.J.phys. Anthrop. 14: 245-273 (1956).

26. Publication no. 370 of the Oregon Regional Primate Research Center, supported in part by the National Institutes of Health Grant no. FR-00163.

27. This investigation was supported by Public Health Service Research Grant nos. HD-02836 and HD02837, and by the Muscular Dystrophy Associations of America, Inc.

28. Requests for reprints should be addressed to: Rose MARY Bocex, Ph.D., Department of Biochemistry, Oregon Regional Primate Research Center, Beaverton, Oregon 97005 (USA). 